\title{
Randomized Group Vs Heterogeneous Group in Developing EFL Argumentative Essay
}

\author{
Joni Alfino ${ }^{1}$, Mohammad Adnan Latief², Utami Widiati², and Ali Saukah² \\ ${ }^{1}$ Bung Hatta University, Indonesia \\ ${ }^{2}$ State University of Malang, Indonesia
}

\section{Abstract}

A theory states that writing is a complicated task and highly complex skill. This theory supports a research finding saying that writing is considered difficult by most of students. Pair work is considered to be able to help EFL students to minimize their problem in EFL writing. This study was intended to compare which group performed the higher score in developing an argumentative essay. There were 23 students (randomized group) and 23 students (heterogeneous group) as the subjects of this study. Before the two groups experienced the treatment, the groups were given a

Corresponding Author: Joni Alfino

joni_alfino@yahoo.com

Received: 18 January 2019 Accepted: 24 March 2019 Published: 31 March 2019

Publishing services provided by Knowledge E

(c) Joni Alfino et al. This article is distributed under the terms of the Creative Commons

Attribution License, which permits unrestricted use and redistribution provided that the original author and source are credited.

Selection and Peer-review under the responsibility of the ICEST 2018 Conference Committee. pre-test to see the homogeneity of the groups. The instrument used in this study was a writing test adapted from IELTS test. The result showed that the subjects in subjects in randomized group $(\mathrm{M}=68.87, \mathrm{SD}=13.815)$ performed better significantly than those in heterogeneous group $(M=57.13, S D=11.190)$. Based on the result, randomized group technique is recommended to be employed in EFL writing class.

Keywords: Randomized Group, Heterogeneous Groups, EFL Argumentative Essay

\section{Introduction}

Many researchers have been paying their attention to pair-work strategy in EFL writing and found several research findings. Baleghizadeh (2009) highlighted that learners who completed the task in pairs outperformed those who attempted it individually. Storch (1999) also found that learners who worked in pairs had more opportunities to communicate in the target language than those in teacher-fronted classrooms. These findings implicitly imply EFL teachers on how to create a strategy in which students have more opportunities to communicate in the target language. Baleghizadeh and Farhesh (2014) investigated the power of pair work to students's motivation and found that pair work had positive contributions to learners' motivations. This means that pairwork can be employed to stimulate students's motivation. Shin, et al (2015) found that students who worked together in pairs assisted each other, thereby recalling more correct idea units 
from the texts and eliminating extraneous information in their writing. These research findings have shown that pair work really, in general, gives a lot of advantages if it is employed in EFL classrooms. The findings discussed above on the merits of pair work are also related to aspects required in writing.

Although the use of pair work in the classroom is relatively limited in use (Storch, 2011), this strategy is believed to have beneficial points. Storch (2007:143) underlines states that pair-work has strong pedagogical and theoretical supports. From the pedagogical aspect, Biria and Jafari (2013:166) affirm that pair-work offers language learners more chances to use the language. From a theoretical point, this strategy is in line with language learning that emphasizes the importance of interaction for learning in order to develop learner's language competence. Dobao (2012:41) asserts that the role of interaction and peer collaboration are considered important in L2 development. In addition, Xiao (2008:106) also points out that paired-peer review gives students benefits in terms of EFL writing proficiency, transferable skills, and self-efficacy. Besides, Mulligan and Garofalo (2011:9) emphasize that collaborative writing (pairwork) is a non- threatening approach for students that results in purposeful usage of the target language across skills and demonstrable improvements in writing. In short, pair-work does not only function as an activity to be employed in teaching-learning process, but it also gives advantages to students in writing performance.

Many research findings have showed that pair work had a significant effect or contribution on students' writing performance. Sorch (1999:363) asserted that collaboration had a positive effect on overall grammatical accuracy. In other study, Storch (2005:168) made a comparison of the products (completed texts) of pairs and individuals. The pairs produced shorter and better texts that had greater grammatical accuracy and linguistic complexity, and were more succinct. They seemed to fulfill the task more competently. In a collaborative study, Wigglesworth and Storch (2009:445) found that collaboration (pair work) impacted positively on accuracy although it does not affect fluency and complexity. Indirectly, these three research findings reveal that pair work is able to facilitate students to improve their skill in using language component (grammar) required in producing good written texts. In addition, pair work also helps students to write effectively in presenting ideas in their essays.

Some researchers also found the effect of pair work toward students' writing performance. Shehadeh (2011:286) found that collaborative writing had an overall significant effect on students' L2 writing. However, this effect varied from one writing skill area to another. Specifically, the effect was significant for content, organization, and vocabulary, 
but not for grammar or mechanics. Globally, her findings are the same as Storch's. However, she also found a different result from Storch's study (2005). Her finding showed that collaborative writing did not have a significant effect on grammar. Meanwhile, Storch found that pairs produced shorter and better texts that had greater grammatical accuracy. The difference was assumed by the fact that they used the subject with different proficiency (based on IELTS score). The subjects' score (average) in Shehade's study was 4. Meanwhile, the subjects' score (average) in Storch's study was 6.5. Although research findings by Shehade on grammar accuracy is different from Storch's, Shehadeh found the significant effect of pair work on some other aspects of writing. These aspects were found to be a problem for students working individually (Sabarun:2006, Attamim: 2007, Ulfiati: 2010, and Isnawati: 2010).

Jafari and Ansari (2012: 128) found that students working in pairs had better writing accuracy than those working individually. This finding can enrich the theory on the merrits of pair work found by Shehadeh (2011) and Storch (2005). In addition, this finding (students working in pairs had better writing accuracy) also has answered research finding by Kasman (2004) and Irawati (2008) in which college students and university graduates were found to have low academic writing. It means that having students to work in pairs can help them to minimize their problem in writing.

Biria and Jafari (2013:164) found that practicing in pairs really improved the overall quality of the learners' writing even though the fluency of written texts did not change significantly. Studets need to be encouraged in order to have good writing quality and this research finding has showed that pair works can meet the target. In other words, pair work can guide students to have a good quality writing.

At last, Meihami, Meihami, and Varmaghani (2013:47) found that collaborative work (pair work) could improve students' grammatical accuracy in their upcoming writings. Their findings match what Storch (1999:363) has found on the effect of pair work on students grammar in writing. Having grammatical accuracy is a must in writing activities because sentences with wrong grammatical patterns can mislead and will not be understandable. Working in pairs was found to be useful for students to improve their grammatical accuracy because writing activites where students correct each other and share ideas with one another guide students to better grammatical accuracy.

\subsection{Research problem}

The target to be reached in this study is the empirical evidence of the effect of pair work types on students' writing quality. Therefore, the researcher formulates the research 
problem as follows: Is there a different writing quality between the students who work in randomized group and those in heterogeneous one?

\section{Methodology}

The researcher carried out this present study at Islamic University of Malang. This campus was chosen because it was the only campus which offered writing III class (argumentative essay is one of genres discussed) when the researcher conducted this study. The target population of this study was the English Department students of the Faculty of Teacher's Training and Education at Islamic University of Malang. The accessible population was sophomores who were taking Writing III course in semester 3, 2016/2017.

This study was carried out for six meetings and each group experienced the same treatment. The following table shows the treatment procedure.

TABLE 1: Treatment Procedure.

\begin{tabular}{|c|c|c|}
\hline \multirow[t]{2}{*}{ DAY } & \multicolumn{2}{|c|}{ GROUP } \\
\hline & HETEROGENEOUS PAIRS & RANDOMIZED PAIRS \\
\hline 1 & Pre-test & Pre-test \\
\hline 2 & $\begin{array}{l}\text { Description on the concept of } \\
\text { argumentative }\end{array}$ & $\begin{array}{l}\text { Description on the concept of } \\
\text { argumentative }\end{array}$ \\
\hline 3 & $\begin{array}{l}\text { Working in pairs do exercise (Introductory } \\
\text { paragraph) }\end{array}$ & $\begin{array}{l}\text { Working in pairs do exercise (Introductory } \\
\text { paragraph) }\end{array}$ \\
\hline 4 & $\begin{array}{l}\text { Working in pairs do exercise (body } \\
\text { paragraph) }\end{array}$ & $\begin{array}{l}\text { Working in pairs do exercise (body } \\
\text { paragraph) }\end{array}$ \\
\hline 5 & $\begin{array}{l}\text { Working in pairs do exercise (concluding } \\
\text { paragraph) }\end{array}$ & $\begin{array}{l}\text { Working in pairs do exercise (concluding } \\
\text { paragraph) }\end{array}$ \\
\hline 6 & Post-test & Post-test \\
\hline
\end{tabular}

The research treatment was carried out in the second to fifth meetings. On the second meeting, the researcher explained the concept of argumentative, including the components of argumentative essay and how to develop each component. The third meeting was used to discuss the concept of an introductory paragraph and complete the task on an introductory paragraph. The fourth meeting was used for a body paragraph. The fifth meeting was used for the concluding paragraph.

In the third meeting, the subjects were given an argumentative topic. Then, they were asked to work in pair to develop the introductory paragraph of the topic. In the process of developing the introductory paragraph, they were asked to employ writing stages (planning, drafting/writing, and editing). In the stage of planning, everyone in each pair was asked to produce at least two or three sentences individually that would be used to 
be general statements and a thesis statement. This means that each group had at least 4-6 sentences. Then, each pair discussed the sentences produced to be an introductory paragraph. In this step, they could add necessary sentence/s and eliminate improper sentence/s in order that their introductory paragraph was acceptable and proper. While they were discussing the sentences in order to be introductory paragraph, they were reminded that their introductory paragraph had to consist of some general statements and a thesis statement that had to be put as the final sentence of introductory paragraph.

In the $4^{\text {th }}$ meeting, the researcher first discussed some points related to the introductory paragraphs developed by the subjects for 10-15 minutes in previous meeting. After that, the researcher presented and discussed the concept of a body paragraph and how to develop the body paragraph. Then, the subjects were asked to develop a body paragraph. In this phase, they were reminded that their body paragraph had to develop the thesis statement formulated at the end of introductory paragraph. In the process of developing the body paragraph, the subjects were also asked to employ writing stages (planning, drafting/writing, and editing). In the stage of planning, everyone in each pair was asked to produce at least three sentences individually. In drafting/writing and editing stages, each pair discussed sentences produced (at least 6) for the body paragraph. Here, they were also reminded that their body paragraph had to consist of a topic sentence and several supporting sentences.

In the $5^{\text {th }}$ meeting, the researcher first discussed some points related to the body paragraphs developed by the subjects for 10-15 minutes in the previous meeting. As soon as the discussion was completed, the researcher presented and discussed the concept of a concluding paragraph and how to develop the concluding paragraph. Here, they were informed that they could use a conclusion transition signal such as in conclusion, in summary, or to summarize. Next, they could either summarize the main points of the essay or rewrite the thesis statement in different words. After that, the researcher had the subjects develop concluding paragraph. In the process of developing the concluding paragraph, the subjects were asked to make the concluding paragraph individually based on the thesis statement and body paragraph. Then, everybody brought the concluding paragraph developed to the group and compared it to one developed by their partner. The comparison was carried out in order that they could produce a proper concluding paragraph.

When the subjects were developing introductory, body, and concluding paragraphs, the researcher had to walk around the classroom, moving from one group to another. This activity was carried out to make sure that the subjects really worked in pairs as 
intended. In addition, this was conducted to minimize the chance of any pair dominating his/her partner.

To collect the required data (students' score) for this study, the researcher used a writing test as his research instrument. The writing test was used because the writing test result could measure students' performance. This is in line with Zare-ee's statement (2013) saying that EFL students' writing quality can be drawn as their EFL writing skill through their performance.

The test to be used in this study was a direct writing. This kind of format was a better way to test students' writing ability than indirect one because the direct writing test could provide better accuracy. This is in line with Latief (2014:234) stating that students writing skill can only be assessed from students' actual piece of writing.

In developing the writing prompt for this study, the researher adapted one available in IELTS test for two reasons. First, IELTS is a standard test recognised internationally. As a standard test recognised internationally, IELTS must have a clear writing prompt. In addition, it also shows that the test takers are required to do the same task. Second, IELTS also contains an argumentative writing test that requires test takers to present a solution to a problem, present and justify an opinion, and evaluate and challenge an ideas, evidences or arguments (Cambrridge Practice Test for IELTS 9, 2013:3).

\subsection{Finding and discussion}

In line with the research problem formulated previously (to investigate different writing quality among students working with heterogeneous pairs and those working with homogeneous pairs), the researcher analyzed the data to detect if there were different mean among the two groups. Based on the result of data analysis, it was found that the subjects in the randomized group performed better significantly than those in heterogeneous group. The result of data analysis also revealed that there were different means among two groups (Randomized pair/RD and Heterogeneous pair/HT). In addition, the table also showed that the subjects in the randomized pair performed the higher mean $(M=68.87, S D=13.815)$ than those in heterogenous group $(M=57.13, S D=11.190)$. Next, the table also revealed the standard error for each group. The standard error is the standard deviation of sample means. A small standard error indicates that most sample means are similar to the population mean and so the sample is likely to be an accurate reflection of the population (Field, 2009:43).

Then, the researcher also investigated which groups had the significant difference. The significant difference of means can be detected if the sign star $\left(^{*}\right)$ is available in 
Mean Difference column. The following Table 1 showed clearly which groups had the sign $\left({ }^{*}\right)$ in Mean Difference column.

TABLE 2: Multiple Comparisons.

\begin{tabular}{|c|c|c|c|c|c|c|c|}
\hline \multicolumn{8}{|c|}{ Dependent Variable: Writing Quality } \\
\hline & \multirow[t]{2}{*}{$\begin{array}{l}\text { (I) } \\
\text { Pair-work } \\
\text { Type }\end{array}$} & \multirow[t]{2}{*}{$\begin{array}{c}(\mathrm{J}) \\
\text { Pair-work } \\
\text { Type }\end{array}$} & \multirow[t]{2}{*}{$\begin{array}{c}\text { Mean } \\
\text { Difference } \\
(I-J)\end{array}$} & \multirow[t]{2}{*}{ Std. Error } & \multirow[t]{2}{*}{ Sig. } & \multicolumn{2}{|c|}{$\begin{array}{l}95 \% \text { Confidence Inter- } \\
\text { val }\end{array}$} \\
\hline & & & & & & $\begin{array}{l}\text { Lower } \\
\text { Bound }\end{array}$ & $\begin{array}{l}\text { Upper } \\
\text { Bound }\end{array}$ \\
\hline \multirow[t]{6}{*}{ Tukey HSD } & $\mathrm{HM}$ & HT & 7.036 & 3.855 & .170 & -2.22 & 16.30 \\
\hline & & $\mathrm{RD}$ & -4.703 & 3.855 & .446 & -13.96 & 4.56 \\
\hline & $\mathrm{HT}$ & HM & -7.036 & 3.855 & .170 & -16.30 & 2.22 \\
\hline & & $\mathrm{RD}$ & $-11.739^{*}$ & 3.612 & .005 & -20.42 & -3.06 \\
\hline & $\mathrm{RD}$ & HM & 4.703 & 3.855 & .446 & -4.56 & 13.96 \\
\hline & & $\mathrm{HT}$ & $11.739^{*}$ & 3.612 & .005 & 3.06 & 20.42 \\
\hline \multirow[t]{6}{*}{ Bonferroni } & HM & HT & 7.036 & 3.855 & .219 & -2.45 & 16.53 \\
\hline & & $\mathrm{RD}$ & -4.703 & 3.855 & .681 & -14.19 & 4.79 \\
\hline & $\mathrm{HT}$ & HM & -7.036 & 3.855 & .219 & -16.53 & 2.45 \\
\hline & & $\mathrm{RD}$ & $-11.739^{*}$ & 3.612 & .006 & -20.63 & -2.85 \\
\hline & $\mathrm{RD}$ & HM & 4.703 & 3.855 & .681 & -4.79 & 14.19 \\
\hline & & $\mathrm{HT}$ & $11.739^{*}$ & 3.612 & .006 & 2.85 & 20.63 \\
\hline
\end{tabular}

Based on the Table 3.4, it was found that ramdomized group was significantly different from heterogeneous one. Tukey's test and Bonferroni's test showed the same result related to the significant difference.

What was found in this study reveals that there is a strategy, randomized grouping that can help EFL students perform better in EFL writing than heterogeneous grouping. Previously, Eckley (2014) conducted a study to discover what type of cooperative learning has the best result /educational outcomes. His research finding was that students from heterogeneous groups performed better working than homogenous groups. Then, Fauziah and Latief (2015) also investigated the effect of working in Heterogeneous and Homogeneous pairs on the students' writing skill. Their research finding was that the quality of descriptive essays produced individually by the students from heterogeneous group was on the average significantly better than the quality of descriptive essays produced by the students from the homogeneous group. What was found by Eckley 
and Fauziah \& Latief above means that heterogeneous group has better result than homogeneous group to students' achievement.

\section{Conclusion and Recommendation}

This study was aimed at investigating the comparison of writing quality of students working in randomized group and those in heterogeneous group. Based on the result of data analysis, it was found that the subjects in the randomized group performed better than those in heterogeneous group. Based on the result of data analysis, the researcher draws three recommendations. First, the randomized pair strategy is recommended to be employed in EFL writing class because it is proven that the students using this strategy have higher score than heterogeneous group. Second, the following study on pair work is recommended to employ for one semester. Third, it is also recommended to employ these three strategies in genres other than argumentative text in order to compare the effect of pair work in different genres.

\section{References}

[1] Ahmed, A. H. 2010. Students' Problems with Cohesion and Coherence in EFL Essay Writing in Egypt: Different Perspectives. Literacy Information and Computer Education Journal, 1 (4): 211-221.

[2] Al-Seyabi, F. \& Tuzlukova, V. 2014. Writing Problems and Strategies: An Investigative Study in the Omani School and University Context. Asian Journal of Social Sciences \& Humanities, 3 (4): 37-48.

[3] Attamim, Z. 2007. The Implementation of Cooperative Learning to Improve students' Proficiency in Writing paragraph at Muhammadyah University of Ponorogo. Unpublished Thesis. Malang: Graduate Program, State University of Malang.

[4] Baleghizadeh, S. 2009. Investigating the Effectiveness of Pair Work on a Conversational Cloze Task in EFL Classes. TESL Reporter, 42 (2): 1-12.

[5] Baleghizadeh, S. \& Farhesh, S.2014. The Impact of Pair Work on EFL Learners' Motivation. MEXTESOL Journal, 38 (3); 1-11.

[6] Baret, N. E. \& Chen, L. 2011. English Article Errors in Taiwanese College Students' EFL Writing. Computational Linguistics and Chinese Language Processing, 16 (3): 1-20.

[7] Biria, R. \& Jafari, S. 2013. The Impact of Collaborative Writing on the Writing Fluency of Iranian EFL Learners. Journal of Language Teaching and Research, 4 (1): 164-175. 
[8] Cahyono, B. Y. \&Widiati, U. 2011. The Teaching of English as a foreign Language in Indonesia. Malang: State University of Malang Press.

[9] Chen, C. W. 2012. Collaborative Writing in an EFL University Classroom Context:Voices from Students. Asian Journal of English Language Teaching, 22: 25-43

[10] Dobao, A. F. 2012. Collaborative Writing Tasks in the L2 Classroom: Comparing

[11] Group, Pair, and Individual Work. Journal of Second Language Writing, 21: 40-58

[12] Eckley, M. E. 2014. What Type of Cooperative Learning Has the Best Result /Educational Outcomes. Unpublished Thesis. Fredonia: the State University of New York at Fredonia.

[13] Fauziah, H. \& Latief, M. A. 2015. The Effect of Working in Heterogeneous and Homogeneous Pairs on the Students' Writing Skill. Arab World English Journal (AWEJ),6 (2): 174-188.

[14] Ghafoori, N. 2009. A Comparative Study of the Effect of Homogeneous andHeterogeneous Dyadic Interaction on the Development of EFL Learners' Writing Skill. Unpublished Dissertation. Teheran: Islamic Azad University, Science and Research Branch.

[15] Hammad, E. A. 2014. Palestinian University Students' Problems with EFL Essay Writing in an Instructional Setting. Journal of Second and Multiple Language Acquisition, 2 (1): 1-21.

[16] Irawati, E. 2008. Pre-Writing and Drafting Strategies of Graduate Students in Writing Term-Papers in English: A Case Study. Unpublished Dissertation. Malang: Graduate Program, State University of Malang.

[17] Isnawati, I. 2010. Improving the English Writing Skill of the Third Semester English Department Students of STAIN Tulungagung Using Task-Based Language Teaching. Unpublished Thesis. Malang: Graduate Program, State University of Malang.

[18] Jafari, N. \& Ansari, D. N. 2012. The Effect of Collaboration on Iranian EFL Learners' Writing Accuracy. International Education Studies, 5 (2): 125-131.

[19] Javid, C. Z. \& Umer, M. 2014. Saudi EFL Learnres' Writing Problems: A Move Toward Solution. Paper presented in the Global Summit on Education. WorlConference.net, Kuala Lumpur, 4-5 March.

[20] Kasman, S. 2004. The Effect of Using Formal Outlines in Writing Exposition. Unpublished Dissertation. Malang: Graduate Program, State University of Malang.

[21] Kwon, C. 2014. Students' Perspectives on Group Work and Use of L1: Academic Writing in a University EFL Course in Thailand. Second Language Studies, 33(1): 85124. 
[22] Latief, M. A. 2014. Research Methods on Language Learning: An Introduction. Malang: UM Press.

[23] Maftoon, P. \& Ghafoori. 2009. A Comparative Study of the Effect of Homogeneous and Heterogeneous Collaborative Interaction on theDevelopment of EFL Learners' Writing Skill. The Journal of Applied Linguistics, 2 (1): 127-158.

[24] Meihami, H., Meihami, B., \& Varmaghani, Z. 2013. The Effect of Collaborative Writing on EFL Students' Grammatical Accuracy. International Letters of Social and Humanistic Sciences, 11: 47-56.

[25] Mulligan, C. \& Garofalo, R. 2011. A Collaborative Writing Approach: Methodology and Student Assessment. The Language Teacher, 35 (5): 5-10.

[26] Richards, J. C. \&Renandya, W. A. 2002.Mthodology in Language Teaching: An Anthology of Current Practice.Cambridge: Cambridge University Press.

[27] Sabarun, 2006. Improving Writing Ability of Fifth Semester Students of English Department of State University of Malang through Cooperative Learning Strategy. Unpublished Thesis. Malang: Graduate Program, State University of Malang.

[28] Shehadeh, A. 2011. Effects and Student Perceptions of Collaborative Writing in L2. Journal of Second Language Writing, 20: 286-305.

[29] Shin, S. Y. 2015. The effects of L2 Proficiency Differences in Pairs on IdeaUnits in a Collaborative Text Reconstruction Task. Language Teaching Research: 1-21.

[30] Storch, N. 1999. Are Two Heads Better Than One? Pair Work and Grammatical Accuracy. System, 7:363-374.

[31] Storch, N. 2005. Collaborative Writing: Product, Process, and Students' Reflections. Journal of Second Language Writing, 14: 153-173.

[32] Storch, N. 2007. Investigating the Merits of Pair Work on a Text Editing Task in ESL Classes. Language Teaching Research, 11 (2): 143-159.

[33] Storch, N. 2011. Collaborative Writing in L2 Contexts: Processes, Outcomes, and Future Directions. Annual Review of Applied Linguistics. 31: 275-288.

[34] Tsai, Y. R \& Lin, C. F. 2012. Investigating the Effects of Applying Monitoring Strategy in EFL Writing Instruction. International Journal of Business and Social Science. 3 (13): 205-216.

[35] Ulfiati, T. 2010. Cohesive Devices in Papers Written by English Department Students of State University of Malang. Unpublished Thesis. Malang: Graduate Program, State University of Malang.

[36] Wigglesworth, G. \& Storch, N. 2009. Pair versus Individual Writing: Effects on Fluency, Complexity and Accuracy. Language Testing, 26 (3): 445-466. 
[37] Xiao, J. 2008. Paired Peer Review in a Distance-taught EFL Writing Course. The Journal of Asia TEFL, 5 (4): 85-115.

[38] Zakaria, A. A. O. \& Mugaddam. A. R. H. 2013. An Assessment of the Written Performance of the Sudanese EFL University Learners: A Communicative Approach to Writing. World Journal of English Language, 3 (4): 1-10.

[39] Zare-ee, A. 2011. Does English Proficiency Level Predict Writing Speed, Length, and Quality?. AWEJ, 2.(3): 128-140 